\title{
Nakit Akışlarının Sağlandığı Faaliyetler Modeli İle İşletmelerin Nakit Akış Profillerinin İncelenmesi: BİST 30, BİST 50 Ve BİST 100 Endeksleri Karşılaştırması*
}

\author{
Seyhan ÇİL KOÇYİĞİT** \\ Şükran GÜNGÖR TANÇ***
}

\section{ÖZET}

İşletmelerin sürdürülebilirliklerini sağlamaları için düzenli etkin bir nakit akış sistemi önemli bir husus olarak görülmektedir. Başarıll işletmelerin nakit akış sistemlerinin de; işletme faaliyetleri, yatırım faaliyetleri ve finansman faaliyetleri üzerindeki olumlu etkisi beklenmektedir. Bu bağlamda; çalışmanın temel amacı; 2020 yılında BIST 100 kapsamında yer alan bankacılık ve sigortacılık sektörü dışındaki işletmelerin geçmiş 5 yıllık (2015-2019 yıllarına ait) nakit akış tablolarının "nakit akışlarının sağlandığ faaliyetler modeli" yöntemleri ile analiz edilerek, finansal sonuçların BIST 30 , BIST 50 ve BIST 100 endeksleri kapsamında karşılaştırılmasıdır. Araştırma sonucunda; her bir endeks kapsamındaki işletmelerin çoğunlukla model 2 "olgun başarll bir işletme” profiline sahip olduklarl görülmüştür. BIST 30 kapsamındaki işletmelerin araştırma kapsamındaki BIST 50 ve BIST 100'de yer alan işletmelere göre daha çok model 2 "olgun başarılı bir işletme" profiline sahip olduklarl tespit edilmiştir.

Anahtar Kelimeler: Nakit Akış Tablosu, BIST 30, BIST 50, BIST 100

JEL Sinıflandırması: M40, M49, G15

\section{Analysis of Cash Flow Profiles of Buitnesses with the Model of Activities with Cash} Flows: Comparison of BIST 30, BIST 50 and BIST 100 Indexes

\section{ABSTRACT}

A regular effective cash flow system is seen as an important issue for businesses to ensure their sustainability. In the cash flow systems of successful businesses; It is expected to have a positive impact on operating activities, investment activities and financing activities. In this context; The main purpose of the study; In 2020, the past 5-year (2015-2019) cash flow statements of businesses excluding the banking and insurance sector within the scope of BIST 100 are analyzed using the "operations model where cash flows are provided" methods, and the financial results are analyzed within the scope of BIST 30, BIST 50 and BIST 100 indices comparison of scope. As a result of the research; It has been observed that the companies covered bye achindex mostly have a model 2 "mature successful business" profile. It has been determined that businesses within the scope of BIST 30 have a model 2 "mature successful business" profile more than those in BIST 50 and BIST 100 within the scope of there search.

Keywords: Cash Flow Statement, BIST 30, BIST 50, BIST 100

Jel Classification: M40, M49, G15

\footnotetext{
* Bu makale, 23-25 Nisan 2021 tarihleri arasında gerçekleştirilen VI. Uluslararası Muhasebe ve Finans Sempozyumunda bildiri olarak sunulmuştur.

Makale Gönderim Tarihi: 08.06.2021, Makale Kabul Tarihi: 22.07.2021 , Makale Türü: Nicel Analiz

** Prof. Dr., Ankara Hacı Bayram Veli Üniversitesi, seyhan.cil@hbv.edu.tr, ORCID: 0000-0003-1012-3605.

*** Prof. Dr., Nevşehir Hacı Bektaş Veli Üniversitesi, sgungor@nevsehir.edu.tr, ORCID: 0000-0002-0675-2479.
} 


\section{GİRiş}

Nakit akış tablosu işletmenin belli bir dönemde nakit durumu hakkında bilgiler vererek, geleceğe yönelik durumu ile ilgili kararlar almasına yardımcı olur. Nakit akış tablosu işletmelerin belli bir dönemde, varlıkların nerelere harcandığını nerelerden nakit girişi sağlandığını gösterir. Ayrıca işletmelerin finansal durum tablosu ve kar zarar tablosundan elde edilemeyen nakit hareketleriyle ilgili birçok bilginin elde edilmesine de yardımcı olur ve etkin bir mali yapıya sahip olan işletmelerin sürekliliğinin sağlanmasında, hedeflere ulaşılmasında önemli bir rol oynamaktadır. Belirli ölçüde nakit akışı sağlayan işletmelerin; faaliyetlerini sürdürebilmesi, borçlarını ve diğer yükümlülüklerini yerine getirebilmeleri mümkün olabilmektedir.

İşletmeler kar elde ediyor gibi görünebilir ancak, yeterli düzeyde yatırım yapacak, borçlarını ödeyecek ve işletme faaliyetlerinin döngüsünü sağlayacak nakit akışına sahip olmadığı sürece kar elde etmesinin ya da karlı görünmesinin çok da anlamlı olmadığ1 görülmektedir. Finansal analistler ya da uzmanlar işletmelerin raporlarını yorumlarken ya da karşılaştırırken özellikle gelecekle ilgili alacakları kararlarda yardımcı olması açısından nakit akış tablosu verilerinden yararlanmaktadırlar (Steinbargaand Miller, 2016: 775). Nakit akış tablolarında sunulan işletme faaliyetleri, yatırım faaliyetleri ve finansman faaliyetleri kalemlerinin işletmenin firma değerinin oluşumu üzerinde de önemli etkileri olduğu yapılan çalışmalarla da tespit edilmiştir (Ni vd. 2019: 288).

İşletmelerde yükümlülüklerin yerine getirilerek, faaliyetlerin devam ettirilebilmesi ve işletme varlığının sürdürebilmesi için düzenli bir nakit akışı son derece önemlidir. İşletmelerin nakit giriş ve nakit çıkışlarına ait unsurlarda meydana gelen değişmelerin görülmesine imkan sağlayan ve bilgi kullanıcılarına önemli bilgiler sunan nakit akış tablosu finansal tablo bilgi kullanıcılarının karar verme aşamalarında önemli faydalar sağlar. Nakit akış tablosu, yatırımcılara, kreditörlere ve diğer ilgililere işletmenin nakit yaratma gücünü gösterirken, kar ve nakit mevcudu arasındaki farkların sebepleri hakkında bilgiler verir. Aynı zamanda bütçeleme, planlama, performans yönetimi gibi stratejik kararlar alınmasına da katk1 sağlar (Gücenme Gençoğlu ve Poroy Arsoy, 2006: 67). Nakit akış tablosunun işletme yönetimine sağladığı temel faydaları aşağıdaki gibi sıralamak mümkündür (Şensoy, 2002:56: Williams vd., 2008: 572):

- $\quad$ İşletmenin likidite durumunu değerlendirmek,

- Kâr payı dağıtım politikalarını belirlemek,

- Yatırım ve finansman ihtiyaçlarının planlanmasına yardımcı olmak,

- $\quad$ Kısa süreli finansmana ihtiyacı olup olmadığını belirlemek,

Yukarda ifade edilen faydalarının yanı sıra Nakit Akış Tablosu, yatırımcı ve borç verenler açısından da işletmelere önemli katkılar sağlamakta olup, bu katkılar aşağıdaki gibidir (Şensoy, 2002:56):

- İşletme yöneticilerinin nakit akışlarını yönetebilme durumunu değerlendirmek,

- Isşletmenin gelecekte olumlu nakit akışı yaratabilme durumunu değerlendirmek,

- $\quad$ Isşletmelerin borç ödeme kapasitesini değerlendirmek,

- $\quad$ İşletmelerin faiz ve kâr payı ödeme kapasitesini değerlendirmek, 
- $\quad$ İşletmelerin ek finansman ihtiyaçlarının olup olmadığını değerlendirebilmek,

- Yatırım ve finansman faaliyetlerinin nakit ve nakit dişı etkilerini göstermek,

- $\quad$ Gelir tablosunda yer alan net kâr rakamı ile faaliyetlerden doğan net nakit akışı arasındaki farkları açıklamak,

- Finansal analiz açısından karşılaştırılacak işletmeler tarafından uygulanan farklı muhasebe politikaları sonucunda ortaya çıkacak etkileri azaltarak daha tutarlı yorum yapılmasına olanak sağlamaktır.

Bütün bunlar dikkate alınarak değerlendirildiğinde, nakit akış tabloları ile ilgili Ülkemizdeki düzenlemeler aşağıda özetlenmeye çalışılmıştır.

Nakit akış tablosu Türkiye'de TFRS'ye tabi olan bağımsız denetime tabi KAYİK (Kamu Yararını İlgilendiren Kuruluşlar)'ler ve BOBİ FRS'ye tabi olan (bağımsız denetime tabi olup da KAYİK dışında kalan) işletmeler tarafından düzenlenmesi zorunlu olan finansal tablolardan biridir. 7 nolu TMS ve BOBİ FRS bölüm 2, nakit akış tablolarını içermektedir.

Nakit akış tablosu bir işletmenin bir raporlama dönemine ait nakit ve nakit benzeri varlıklarında meydana gelen değişmelerin gösterildiği finansal bir tablodur. "Nakit işletmedeki nakit ile vadesiz mevduatı; nakit benzerleri ise tutarı belirli bir nakde kolayca çevrilebilen kısa vadeli ve yüksek likiditeye sahip ve değerindeki değişim riski önemsiz olan yatırımları kapsamaktadır" (TMS 7, m. 6). Ülkemiz uygulaması ve SPK tebliğine göre nakit ve nakit benzeri varlıklar aşağıdaki şekilde sıralanabilir (Özerhan ve Yanık, 2015: 87):

Çekler (vadesiz)

B tipi likit fonlar

Ters-repo işletmelerinden alacaklar

Vadesi 3 aydan kısa olan mevduat

Finansal varlıklardan vadesine 3 aydan az kalmış devlet tahvili ve hazine bonoları veya aktif bir piyasası olan likit diğer borçlanma araçları

Para piyasasından alacaklar

Müşterisi olunan bankanın talepte bulunması durumunda geri ödenmesi gereken ve bakiyeleri sıkl1kla dalgalanabilen bankalar nezdindeki cari hesaplar

Nakit akış tablosu TMS 7'ye göre esas faaliyetlerden, yatırım faaliyetlerinden ve finansman faaliyetlerinden nakit akışları ayrı ayrı gösterilecek şeklinde sınıflandırılarak raporlanır. $\mathrm{Bu}$ faaliyetlerle ilgili nakit akışları, nakit akış tablosunun genel formatını oluşturmaktadır (Bayrakcığolu ve Bayri, 2019: 390).

Işsletme faaliyetleri; bir işletmedeki esas gelir getirici faaliyetlerinden oluşur ve gelir tablosunda raporlanan kar veya zararı oluşturan işlem ve olaylardan kaynaklanır. "Esas faaliyetlerden kaynaklanan nakit akışlarının tutarı, diş finansman kaynaklarına başvurmadan, işletmenin esas faaliyetlerinin; kredilerin geri ödenmesi, çalışma kapasitesinin devam 
ettirilmesi, temettülerin ödenmesi ve yeni yatırımların yapılması için ne ölçüde yeterli nakit akışı yarattığının temel bir göstergesidir. Esas faaliyetlerden kaynaklanan tarihi nakit akışlarının belirli bileşenleriyle ilgili bilgiler, diğer bilgilerle birlikte, esas faaliyetlere ilişkin gelecekteki nakit akışlarının tahmin edilmesinde fayda sağlar" (TMS 7, md.13).

Yatırım faaliyetleri; "bir işletmedeki maddi duran varlıklar, maddi olmayan duran varlıklar, mali duran varlıklar gibi uzun vadeli varlıklar ile nakit benzeri olarak nitelendirilmeyen diğer yatırımların edinilmesi ve elden çıkarılması faaliyetleridir” (TMS 7, m. 6).

"Yatırım faaliyetlerinden kaynaklanan nakit akışları, gelecekte gelir ve nakit akışı yaratması öngörülen kaynaklar için ne ölçüde harcama yapıldığını gösterdiğinden, bu nakit akışlarının ayrı olarak açıklanması önemlidir. Yalnızca, finansal durum tablosunda bir varlığın kayda alınmasına neden olan harcamalar yatırım faaliyeti olarak sınıflandırılabilir" (TMS 7, md.16).

Finansman faaliyetleri; işletmenin ödenmiş sermayesinde ve borçlanmalarında değişikliğe neden olan faaliyetlerdir. Finansman faaliyetleri işletmeye sermaye sağlayanların gelecekteki nakit akışları üzerindeki haklarını gösterdiğinden, bu nakit akışlarının ayrı olarak raporlanması önem arz etmektedir.

"Finansman faaliyetlerinden kaynaklanan nakit akışları, işletmeye sermaye sağlayanların gelecekteki nakit akışları üzerindeki haklarını tahmin etmede faydalı olduğundan, bu nakit akışlarının ayrı olarak açıklanması önemlidir” (TMS 7, md.17).

TMS 7'ye göre; esas faaliyetlerden kaynaklanan nakit akışları doğrudan yöntem veya dolaylı yönteme göre raporlanır:

(a) Doğrudan yöntem. "Bu yöntemde gayrisafi nakit tahsilatlar ve gayrisafi nakit ödemeler ana gruplar itibarıyla açıklanır” (TMS 7, m. 18).

(b) Dolaylı yöntem. "Bu yöntemde dönem kârı veya zararı, nakit akışı yaratmayan işlemlerin, esas faaliyetlerden kaynaklanan geçmiş veya gelecek nakit giriş veya çıkışlarına ilişkin ertelemeler ile tahakkukların ve yatırım veya finansman faaliyetlerinden nakit akışlarıyla ilgili gelir veya gider kalemlerinin etkilerine göre düzeltilir” (TMS 7, md.18).

"Doğrudan yöntemin, gelecekteki nakit akışlarının tahmininde faydalı olabilecek nitelikte ve dolaylı yöntemle elde edilemeyen bilgiler sağlamasından dolayı işletmelerin, esas faaliyetlerden nakit akışlarını raporlarken doğrudan yöntemi kullanmaları teşvik edilir” (TMS 7, md.19).

Bu çalışmanın temel amacı; 2020 yılında BIST 100 kapsamında yer alan bankacılık ve sigortacılık sektörü dışındaki işletmelerin geçmiş 5 yıllık (2015-2019 yıllarına ait) nakit akış tablolarının "Nakit Akışlarının Sağlandığı Faaliyetler Modeli" yöntemleri ile analiz edilmesidir. Bu bağlamda BIST 100 şirketlerinin gerçekten etkin bir nakit akış politikası izleyip izlemedikleri nakit akışlarının sağlandığı faaliyetler modeli ile ölçülerek; BIST 30, BIST 50 ve BIST 100 endeksleri kapsamında nakit akışlarındaki başarılarının değerlendirilmesi amaçlanmış ve araştırma ile ulaşılan bulgular aşağıda sunulmuştur. 


\section{LITERATÜR TARAMASI}

Yapılan literatür taraması sonucunda nakit akış tablosunu analizinin yapıldığı çok sayıda çalışma olduğu görülmüştür. Ancak bu çalışmalarda BIST 30, BIST 50 ve BIST 100 karşılaştırılmasının yer aldığı sadece bir çalışmaya rastlanılmıştır. Bu çalışma Bodur tarafından 2015 yılında yayınlanmıştır. 2014 yılı 2. Endeks döneminde yer alan finans, gayrimenkul yatırım ortaklığı ve spor kulüpleri dışındaki 79 işletmenin nakit akış tabloları BIST 30 ve BIST 50 endeksleri esas alınarak karşılaştırmalı bir şekilde incelenmiştir. Bu araştırma sonucunda; BIST 30 içindeki başarılı firma oranının BIST 50 ve BIST 100'den daha yüksek olduğu görülmüştür.

Karğın ve Aktaş (2011) tarafından yapılan çalışmada, inşaat sektöründe faaliyet gösteren halka açık bir işletmenin, 2006-2010 yıllarını kapsayan "TMS 7- Nakit Akış Tablosu” Standardı'na göre hazırlanmış olan nakit akış tabloları, karşılaştırmalı tablolar analizi, eğilim yüzdeleri analizi, rasyo analizi ve nakit akışlarının sağlandığ faaliyetler modeli kullanılarak analiz edilmiştir. Araştırma sonucunda uygulanan farklı analiz tekniklerinde işletmenin nakit akışlarına ilişkin benzer sonuçlara ulaşılmış olup, özellikle 2008 yılına ait esas faaliyetlerden sağlanan nakit akışlarında azalış olduğu saptanmıştır.

Aktaş vd. (2012) tarafından yapılan çalışmada, halka açık işletmelerin (176 işletme) 2007-2010 yıllarını kapsayan nakit akış tabloları, nakit akışlarının sağlandığı faaliyetler modeline göre incelenmiştir. Çalışmanın sonucunda; incelenen işletmelerin nakit akışları, yıl, sektör ve aktif büyüklükleri temelinde, "Model 2: başarılı işletme", "Model 4: büyüyen işletme", "Model 6: hızlı büyüyen-genç işletme" profillerinde yoğunlaştığı görülmüştür.

Orhan ve Başar (2015) tarafından yapılan ve BIST Ulusal 100 endeksi kapsamındaki işletmelerin nakit akış profilleri ile finansal oranları arasındaki ilişkinin incelendiği çalışma sonucunda; işletmelerin Model 2 "başarılı işletme" profilinde yoğunlaştığ 1 (işletme faaliyetlerinden nakit akışlarının pozitif, yatırım faaliyetlerinden ve finansman faaliyetlerinden nakit akışlarının ise negatif) nakit akışına sahip oldukları tespit edilmiştir.

Cavlak vd. (2017) tarafından yapılan çalışmada BIST 30 kapsamındaki işletmelerin nakit akış tabloları içerik analizine tabi tutulmuştur. Kapsam dahilindeki şirketlerin nakitleri; işletme, yatırım ve finansman faaliyetleri bağlamında oransal olarak ortaya konulmuştur.

Derya Baskan ve Dozen (2019) tarafından yapılan çalışmada BIST 100 endeksinde yer alan 50 işletmenin 2009-2018 dönemlerini kapsayan nakit akış tabloları incelenmiştir. Model 2 profiline sahip işletmelerin; kâr kalitesi, varlık getirisi, öz kaynakların getirisi ve nakit akış likiditesi oranları arasında bir ilişki olup olmadığı araştırılmıştır. Çalışma sonucunda işletmelerin varlıklardan sağladıkları nakit getirileri ve özkaynak getirileri ile işletme faaliyetlerinden sağlanan nakit akışları arasında istatistiksel olarak anlamlı bir ilişki olduğu görülmüştür.

Dereköy (2020) tarafindan yapılan çalışmada, işletmelerin likidite oranları ile nakit akışları arasında herhangi bir ilişkinin olup olmadığı ve ilişkinin olması durumunda bu ilişkinin düzeyi ve yönünün belirlenmesi amaçlanmıştır. Araştırmanın sonucunda, işletme, yatırım ve finansman faaliyetlerinden elde edilen nakit akışları ile likidite oranları arasında istatistiksel olarak anlamlı bir ilişkiye rastlanılmamıştır. 
Akdoğan vd. (2020) tarafından yapılan çalışmada; sermaye araçları BIST’te işlem gören 444 şirketin 2015-2019 dönemine ilişskin mali tablo ve dipnotları incelenmiş olup, işletme faaliyetleri, yatırım faaliyetleri ve finansman faaliyetleriyle ilgili nakit akışları ve bunları oluşturan alt kalemler 13 sektör bazında değerlendirilmiştir. Araştırma sonucunda; bazı sektörler dışında, işletmelerin esas faaliyetlerinden yarattıkları nakit akışlarının olumlu yönde ilerlediği, birçok sektörde yatırım faaliyetlerine büyük tutarlarda harcama yapılarak büyümeye eğilimli oldukları ve esas faaliyet kapasite artırımını hedefledikleri, 2019 yılı hariç finansman faaliyetlerinden kaynaklı yüksek tutarlarda nakit girişleri sağlanmışken, 2019 yılında ciddi bir nakit çıkışı olduğu tespit edilmiştir.

\section{ARAŞTIRMA}

\subsection{Araştırmanın Amacı}

Bu çalışmada;2020 yılında BIST 100 kapsamında yer alan bankacılık ve sigortacılık sektörü dışındaki işletmelerin geçmiş 5 yıllık (2015-2019 yıllarına ait) nakit akış tablolarının "nakit akışlarının sağlandığı faaliyetler modeli" yöntemleri ile analiz edilerek, BIST 30, BIST 50 ve BIST 100 Şirketlerinin başarılarının nakit akışlarının da başarılı bir şekilde yürütülüp yürütülmediğinin tespit edilerek, sonuçların BIST 30, BIST 50 ve BIST 100 endeksleri kapsamında karşılaştırılması amaçlanmıştır.

\subsection{Araştırmanın Kapsamı}

Çalışmaya 2020 y1lı BIST 100 endeksi kapsamındaki bankacılık ve sigortacılık sektörü dişındaki işletmeler dahil edilmiştir. BIST 100 endeksi; BIST 30 ve BIST 50 işletmelerini de kapsadığından, nakit akış tablolarının analiz sonuçları bu endeksler kapsamında karşılaştırılmıştır. BIST 100 kapsamında 88 işletme, BIST 50 kapsamında 40 işletme, BIST 30 kapsamında 23 işletme araştırmada yer almıştır.

\subsection{Araştırmanın Yöntemi}

Çalışmada kapsam dahilindeki nakit akış tablolarının analizinde Gup ve diğ. (1993) tarafından geliştirilen nakit akışlarının sağlandı ğı faaliyetler modeli, esas alınmıştır. Bu modele göre; işletmenin nakit akış profilleri sekiz model altında toplanmaktadır. Bu modeller; işletmenin nakit akış tablosundan alınan işletme, yatırım ve finansman faaliyetlerine ilişkin nakit akışlarının büyüklüklerine bakılmaksızın, nakitlerin izlediği yöne göre yani pozitif (nakit girişi) veya negatif (nakit çıkış1) olmalarına göre ortaya çıkmaktadır. Bu modeller aşağıdaki gibidir (Gup ve diğ. 1993: 74):

Model $1(+,+,+)$ : Nadir Durum. Bu modelde işletme, esas, yatırım ve finansman faaliyetlerinin her üçünden de nakit girişi sağlamaktadır. Böyle bir durumun nadir olabileceği söylenebilir. Böyle bir durumda olan işletmenin gelecekte yüksek tutarda bir nakit çıkışı ile karşılaşması beklenmektedir.

Model 2 (+,-,-): Olgun Başarılı İşletme. Yaygın olarak karşılaşılan bu model, olgunluk aşamasında olan başarılı bir işletme örneği olarak değerlendirilmektedir. İşletmenin 
uzun vadeli borçlarını ve temettü ödemelerini yapmada ve yatırım faaliyetlerini karşılamada esas faaliyetlerden elde edilen nakdîn yeterli olduğu düşünülmektedir.

Model 3 (+,+,-): Gerileyen veya Yeniden Yapılanan İşletme. Çok rastlanılan bir durum olarak düşünülmeyen bu modelde; esas faaliyetlerden ve yatırım faaliyetlerinden kaynaklı nakit akışları pozitif, finansman faaliyetlerinden kaynaklı nakit akışları ise negatiftir. Esas faaliyetlerden ve yatırım faaliyetlerinden kaynaklanan nakit girişlerinin borçların ödenmesinde veya hissedarlara ödeme yapmada kullanıldığı düşünülebilir. Bu modeldeki bir işletme hem kapasitesini hem de yatırım varlıklarını daralttığı için az sayıda karlı yatırım alternatifine sahip bir işletme olarak düşünülebilir.

Model 4 (+,-,+): Büyüyen İşletme. İşletmenin esas faaliyetlerinden kaynaklı nakit akışlarının, yatırım faaliyetlerini karşılamada yetersiz kaldığı düşünülmektedir. İşletme yatırımlarının bir kısmı borçlanma ve özkaynak ile finanse edilmektedir.

Model 5 (-,+,+): Küçülen İşletme. Bu modelde; işletmenin esas faaliyetlerden kaynaklı nakit azalışları, uzun vadeli yatırımlar satılarak, borç alınarak veya özkaynaklar artırılarak kapatılmaya çalışılmaktadır. Uzun vadeli yatırımlardaki azalış büyüme potansiyelinin azaldığının göstergesidir. Bu durumda nadir karşılaşılabilen bir durumdur.

Model 6 (-,-,+): Genç - Hızlı Büyüyen İşletme. Bu modelde; hem esas faaliyetlerden kaynaklı nakit akışı hem de yatırım faaliyetlerinden kaynaklı nakit akışı negatiftir. İşletmede esas faaliyet akışı negatif olsa da yatırım yapılmaktadır. Esas faaliyetlerdeki ve yatırım faaliyetlerindeki bu negatiflik borçlanma ya da öz sermayedeki artışla kısmen de olsa karşılanabilmektedir. Bu modeldeki negatifliğin geçici olduğu ve işletmenin büyüme eğiliminde olduğu düşünülmektedir. Dolayısıyla büyüme eğiliminde olan işletmelerin işletme sermayesi unsurları olan alacaklar ve stoklar gibi kalemlere yönelmesi ve vadesi gelen borçlarını ödeyerek nakit çıkışına neden olması normal bir durum olarak değerlendirilebilir. Yatırımcılar ve borç verenlerde bu durumun geçici olduğunu ve genç hızlı büyüyen bir işletmede yapılan yatırımların sonucunda işletme faaliyetlerinden nakit yaratılacağını düşündüklerinden, borç verme ve ortak olma konusunda istekli davranmaktadırlar.

Model 7 (-,+,-): Likiditasyon Modeli. Bu modelde işletme esas faaliyetlerinden ve finansman faaliyetlerinden negatif nakit akışına sahiptir. Isşletme negatif olan esas faaliyet nakit akışından dolayı borçlarını duran varlıkları satarak ödemektedir. Böyle bir durumdaki işletmelerin ömürlerinin devamı çok uzun süreli olmayacak ve işletmenin tasfiyesi ile karşılaşılabilecektir. Bu durumda nadir karşılaşılabilen bir durumdur.

Model 8 (-,-,-): Nadir Durum Modeli. Bu modelde işletmenin bütün faaliyetlerden kaynaklı nakit akışları negatiftir. Bu modelde işletmenin yeni uzun vadeli varlıklar satın almasından ve borçları ödemesinden dolayı esas faaliyetlerden kaynaklı nakit akışları da negatif olarak gerçekleşmektedir. Böyle bir durumun daha önceden birikmiş olan ve yapılması gereken nakit çıkışlarının yapılmasının sonucu olarak ortaya çıktığı düşünülebilir. 


\subsection{Bulgular}

2020 y1lında BIST 100 kapsamında yer alan bankacılık ve sigortacılık sektörü dışındaki işletmelerin 2015-2019 yıllarına ait nakit akış tablolarının "nakit akışlarının sağlandığı faaliyetler modeli” yöntemleri ile analiz edilmesi sonucu BIST 100, BIST 50 ve BIST 30 endeksi doğrultusunda elde edilen bulgular aşağıdaki gibidir.

Tablo 1. BIST 100 Kapsamındaki İşletmelerin Nakit Akış Profilleri

\begin{tabular}{|l|c|c|c|c|c|c|c|c|c|c|}
\hline MODELLER & \multicolumn{2}{|c|}{2015} & \multicolumn{2}{c|}{2016} & \multicolumn{2}{c|}{2017} & \multicolumn{2}{c|}{2018} & \multicolumn{2}{c|}{2019} \\
\hline & Say1 & Yüzde & Say1 & Yüzde & Say1 & Yüzde & Say1 & Yüzde & Say1 & Yüzde \\
\hline MODEL 1 (+, +, +) & 0 & 0,00 & 0 & 0,00 & 1 & 1,14 & 0 & 0,00 & 0 & 0,00 \\
\hline MODEL 2 (+, -, -) & 42 & 47,73 & 51 & 57,95 & 43 & 48,86 & 45 & 51,14 & 42 & 47,72 \\
\hline MODEL 3 (+, +, -) & 6 & 6,82 & 11 & 12,50 & 7 & 7,95 & 7 & 7,95 & 23 & 26,14 \\
\hline MODEL 4 (+, -, +) & 20 & 22,72 & 16 & 18,18 & 27 & 30,68 & 23 & 26,14 & 13 & 14,77 \\
\hline MODEL 5 (-, +, +) & 2 & 2,27 & 2 & 2,27 & 3 & 3,41 & 4 & 4,55 & 5 & 5,68 \\
\hline MODEL 6 (-, -, +) & 11 & 12,50 & 4 & 4,55 & 7 & 7,95 & 7 & 7,95 & 4 & 4,55 \\
\hline MODEL 7 (-, +, -) & 2 & 2,27 & 0 & 0 & 0 & 0 & 1 & 1,14 & 1 & 1,14 \\
\hline MODEL 8 (-, -, -) & 5 & 5,68 & 4 & 4,55 & 0 & 0 & 1 & 1,14 & 0 & 0 \\
\hline Toplam & 88 & 100 & 88 & 100 & 88 & 100 & 88 & 100 & 88 & 100 \\
\hline
\end{tabular}

Tablo 2. BIST 50 Kapsamındaki İşletmelerin Nakit Akış Profilleri

\begin{tabular}{|l|c|c|c|c|c|c|c|c|c|c|}
\hline MODELLER & \multicolumn{2}{|c|}{2015} & \multicolumn{2}{|c|}{2016} & \multicolumn{2}{c|}{2017} & \multicolumn{2}{c|}{2018} & \multicolumn{2}{c|}{2019} \\
\hline & Say1 & Yüzde & Say1 & Yüzde & Say1 & Yüzde & Say1 & Yüzde & Say1 & Yüzde \\
\hline MODEL 1 (+, +, +) & 0 & 0,00 & 0 & 0,00 & 0 & 0,00 & 0 & 0,00 & 0 & 0,00 \\
\hline MODEL 2 (+, -, -) & 20 & 50,00 & 26 & 65,00 & 19 & 47,50 & 18 & 45,00 & 20 & 50,00 \\
\hline MODEL 3 (+, +, -) & 3 & 7,50 & 6 & 15,00 & 5 & 12,50 & 2 & 5,00 & 10 & 25,00 \\
\hline MODEL 4 (+, -, +) & 12 & 30,0 & 4 & 10,00 & 11 & 27,50 & 13 & 32,50 & 6 & 15,00 \\
\hline MODEL 5 (-, +, +) & 1 & 2,50 & 2 & 5,00 & 1 & 2,50 & 3 & 7,50 & 1 & 2,50 \\
\hline MODEL 6 (-, -, +) & 2 & 5,00 & 2 & 5,00 & 4 & 10,00 & 2 & 5,00 & 2 & 5,00 \\
\hline MODEL 7 (-, +, -) & 1 & 2,50 & 0 & 0,00 & 0 & 0,00 & 1 & 2,50 & 1 & 2,50 \\
\hline MODEL 8 (-, -, -) & 1 & 2,50 & 0 & 0,00 & 0 & 0,00 & 1 & 2,50 & 0 & 0,00 \\
\hline Toplam & 40 & 100 & 40 & 100 & 40 & 100 & 40 & 100 & 40 & 100,00 \\
\hline
\end{tabular}


Tablo 3. BIST30 Kapsamındaki İşletmelerin Nakit Akış Profilleri

\begin{tabular}{|l|c|c|c|c|c|c|c|c|c|c|}
\hline MODELLER & \multicolumn{2}{|c|}{2015} & \multicolumn{2}{c|}{2016} & \multicolumn{2}{c|}{2017} & \multicolumn{2}{c|}{2018} & \multicolumn{2}{c|}{2019} \\
\hline & Say1 & Yüzde & Say1 & Yüzde & Say1 & Yüzde & Say1 & Yüzde & Say1 & Yüzde \\
\hline MODEL 1 (+, +, +) & 0 & 0,00 & 0 & 0,00 & 0 & 0,00 & 0 & 0,00 & 0 & 0,00 \\
\hline MODEL 2 (+, -, -) & 13 & 56,52 & 16 & 69,57 & 13 & 56,52 & 11 & 47,83 & 14 & 60,87 \\
\hline MODEL 3 (+, +, -) & 1 & 4,35 & 3 & 13,04 & 3 & 13,04 & 0 & 0,00 & 4 & 17,39 \\
\hline MODEL 4 (+, -, +) & 6 & 26,09 & 3 & 13,04 & 6 & 26,09 & 7 & 30,43 & 3 & 13,04 \\
\hline MODEL 5 (-, +, +) & 0 & 0,00 & 1 & 4,35 & 1 & 4,35 & 2 & 8,70 & 0 & 0,00 \\
\hline MODEL 6 (-, -, +) & 1 & 4,35 & 0 & 0,00 & 0 & 0,00 & 1 & 4,35 & 2 & 8,70 \\
\hline MODEL 7 (-, +, -) & 1 & 4,35 & 0 & 0,00 & 0 & 0,00 & 1 & 4,35 & 0 & 0,00 \\
\hline MODEL 8 (-, -, -) & 1 & 4,35 & 0 & 0,00 & 0 & 0,00 & 1 & 4,35 & 0 & 0,00 \\
\hline Toplam & 23 & 100 & 23 & 100 & 23 & 100 & 23 & 100 & 23 & 100 \\
\hline
\end{tabular}

Nakit akışlarının sağlandığı faaliyetler modeline göre her yıl boyunca BIST 100, BIST 50 ve BIST 30 kapsamındaki işletmelerin çoğunlukla model 2 "olgun başarılı bir işletme" profiline sahip oldukları görülmüştür. Model 2'ye sahiplik oranı BIST 30 kapsamındaki işletmelerde diğer endekslerde yer alan işletmelere göre daha fazladır. BIST 30' da model 2 'ye sahiplik oran $1 \% 58,28$, BIST 50'de \% 51,50, BIST 100'de de \% 50,68 oranındadir.

Araştırma sonuçlarına göre, araştırma kapsamındaki işletmelerin çoğunlukla model 2 profiline sahip olmalarından dolayı başarılı işletmelerin çoğunlukta olduğu, bu işletmelerin uzun vadeli borçlarını ve temettü ödemelerini yapmada ve yatırım faaliyetlerini karşılamada esas faaliyetlerden elde edilen nakitlerinin yeterli olduğu söylenebilir.

İkinci sırada 2019 yılı hariç olmak üzere tüm yıllarda hem BIST 100, BIST 50 ve BIST 30 kapsamındaki işletmelerin model 4 "büyüyen işletme" profiline sahip olduğu görülmüştür. 2019 yılı hariç olmak üzere tüm yıllarda ikinci sırada yer alan model 4 profiline sahip işletmelerin; esas faaliyetlerden kaynaklı nakit akışları pozitif, yatırım faaliyetlerinden kaynaklı nakit akışları negatif ve yatırım kaynaklarından sağlanan nakit akışları da pozitiftir. $\mathrm{Bu}$ bağlamda esas faaliyetlerinden kaynaklı nakit akışlarının, yatırım faaliyetlerini karşılamada yetersiz kaldığ 1 ve işletmelerin yatırımlarının bir kısmını borçlanma ve özkaynak ile finanse ettikleri söylenebilir.

2019 yılında ise ikinci sırada tüm endekslerde model 3 "gerileyen veya yeniden yapılanan işletme" profiline sahip olan işletmelerin çoğunlukta olduğu görülmüştür. 2019 yılında model 3'e sahiplik oranı çok az bir farkla BIST 100 kapsamındaki işletmelerde daha fazladır. 2019 yılında bütün endekslerde model 4 üçüncü sırada yer almıştır. Model 3'ün hakim olduğu işletmelerde esas faaliyetlerden ve yatırım faaliyetlerinden kaynaklı nakit akışları pozitif, finansman faaliyetlerinden kaynaklı nakit akışları ise negatiftir. Bu durumun sebebi; esas faaliyetlerden ve yatırım faaliyetlerinden kaynaklanan nakit girişlerinin borçların ödenmesinde veya hissedarlara ödeme yapılmasında kullanılması kaynakliysa bu durum finansal açıdan riskli bir durumu ifade eder. Ancak bu durumun işletmelerin duran varlıklarını 
yenileme maksadıyla elden çıkarmasından kaynaklıysa işletmelerin yeniden yapılanma sürecinde olduklarının bir göstergesi olabilir.

Çok “nadir” gözüken model 1 ise sadece 2017 y1lında ve BIST 100 kapsamındaki bir işletmede görülmüştür. Bu işletmede gelecekte yüksek tutarda bir nakit çıkışı ile karşılaşacağı beklenmektedir. BIST 30 ve BIST 50 endeksindeki işletmelerde model 1'e rastlanılmamıştır.

"Nadir" gözüken diğer bir model olan Model 8 bütün faaliyetlerden kaynaklı nakit akışları negatif olan bir modeldir. Model 8 en fazla 2015 yılında BIST 100 kapsamındaki 5 işletmede $(\% 5,68)$ ve yine 2016 yılında BIST 100 kapsamındaki 4 işletmede $(\% 4,55)$ görülmüş̧ür. 2015 yılındaki bu işletmelerden sadece 1 tanesi BIST 30 ve BIST 50 endeksinde de yer alan bir işletmedir. $\mathrm{Bu}$ işletmelerde yeni uzun vadeli varlıklar satın alındığı ve borçların ödemesinden dolayı esas faaliyetlerden kaynaklı nakit akışların da negatif olarak gerçekleştiği düşünebilir.

\section{SONUÇ VE ÖNERILER}

BIST 30, BIST 50 ve BIST 100 kapsamında yer alan bankacılık ve sigortacılık sektörü dışındaki işletmelerin 2015-2019 yıllarına ait nakit akış tablolarının "nakit akışlarının sağlandığı faaliyetler modeli" yöntemleri ile analiz edilerek, etkin bir nakit akış politikası izleyip izlemediklerinin ortaya konulmasının amaçlandığı bu çalışma ile endeksler bazında genel olarak benzer bulgulara ulaşılsa da birtakım farklılıkların olduğu görülmüştür. Çalışma ile ulaşılan sonuçlar aşağıdaki gibidir:

Her bir endeks kapsamındaki işletmelerin çoğunlukla model 2 "olgun başarılı bir işletme" profiline sahip oldukları görülmüştür. Ancak model 2'ye sahiplik oranı BIST 30 kapsamındaki işletmelerde diğer endekslerdeki şirketlere göre daha fazla olduğu dikkati çekmiştir. İkinci sırada 2019 yılı hariç olmak üzere tüm yıllarda hem BIST 100, BIST 50 ve BIST 30 kapsamındaki işletmelerde model 4 "büyüyen işletme" profiline sahip olunduğu, 2019 yılında ise ikinci sırada tüm endekslerde model 3 "gerileyen veya yeniden yapılanan işletme" profiline sahip olan işletmelerin çoğunlukta olduğu görülmüştür.

Çok "nadir" gözüken model 1 ise sadece 2017 yılında ve BIST 100 kapsamındaki bir işletmede görülmüştür.

"Nadir" gözüken diğer bir model olan Model 8 en fazla 2015 yılında BIST 100 kapsamındaki 5 işletmede $(\%$ 5,68) ve yine 2016 yılında BIST 100 kapsamındaki 4 işletmede (\% 4,55) görülmüştür. 2015 yılındaki bu işletmelerden sadece 1 tanesi BIST 30 ve BIST 50 endeksinde de yer alan bir işletmedir. Genel olarak yapılan analiz sonucunda nakit akışlarının etkinliğinde çok başarılı olarak görülen işletmeler BIST 30'da yer alan model 2 "olgun başarılı bir işletme" profiline sahip olan işletmeler olup, BIST başarıları nakit akışlarındaki başarıları ile de doğrudan ilişkili işletmeler görüşü oluşturulabilir. Literatürde incelenen çalışmaların sonucu ile yapılan mevcut çalışma sonuçları karşılaştırıldığında özellikle, BIST 30 işletmelerinin daha çok Model 2 "olgun başarılı bir işletme” profilinde ağırlıklı olarak yer aldıkları tespit edilmiş olup, analiz yılları farklılaşsa da başarı faktörlerinin ve göstergelerinin yaklaşık sonuçlar verdiği görülmüştür. 
Nakit akış tablosu analizinde uygulaması kolay olan ancak nakit akış rakamlarının büyüklüklerini dikkate almamasının eleştiri konusu olduğu bu yöntemin, karşılaştırmalı tablolar analizi, eğilim yüzdeleri analizi ve oran analizi yöntemleri ile beraber uygulanmasının ve bu yönteme diğer yöntemlerin tamamlayıcısı olarak yer verilmesinin karar almada finansal tablo bilgi kullanıcılarına daha fazla katkı vereceği söylenebilir.

Literatüre bakıldığında nakit akışlarının sağlandığ faaliyetler modeli ile işletmelerin nakit akış profillerinin daha çok BIST'te faaliyet gösteren bütün işletmelere uygulandığı tespit edilmiştir. Daha sonraki çalışmalarda, BOBİ FRS kapsamındaki işletmelerin nakit akış profillerinin tespiti yapılarak bu çalışma geliştirilebilir.

\section{KAYNAKLAR}

Akdoğan, Nalan -Küçüktop, Fatma Beyza - Açıkgöz, Türker (2020), "Borsa İstanbul'da Kayıtlı Şirketlerin 2015-2020 Yıllarına Ait Nakit Akış Tablolarının Sektörler İtibariyle İncelenmesi ve Sektörlerin Nakit Hareketlerinin Değerlendirilmesi”, Muhasebe ve Denetime Bakış, 20 (61), ss. 1-36.

Aktaş, Rabia -Karğın, Sibel - Karğın, Mahmut (2012), "Nakit Akışlarının Sağlandığı Faaliyetler Yöntemi İle İşletmelerin Nakit Akış Profillerinin İncelenmesi”, Muhasebe Finansman Dergisi, (56), ss. 101-118.

Bayrakcığlu, Süleyman -Bayri, Osman (2019), “Türkiye'de Nakit Akışlarının Sunumunda Yöntem Tercihlerinin Değerlendirilmesi ve Brüt Yönteme Göre Raporlanmış Nakit Akış Tablolarının İncelenmesi”, Süleyman Demirel Üniversitesi İktisadi ve İdari Bilimler Fakültesi Dergisi, 24 (3), ss. 385-416.

BOBİ FRS Bölüm 2 Nakit Akış Tablosu Standardı https://www.kgk.gov.tr/Portalv2Uploads/files/PDF\%20linkleri/bobi_frs.PDF (Erişim Tarihi:10 .03. 2021).

Bodur, Gülşirin (2015), Nakit Akış Tablolarının Analizi, Başkent Üniversitesi Sosyal Bilimler Enstitüsü Yayınlanmamış Yüksek Lisans Tezi, Ankara.

Cavlak, Hakan - Cebeci, Yasin - Güneş, Necati (2017), "Nakit Akış Tablolarının İçerik Analizi Yöntemi İle Değerlendirilmesi”, International Journal of Academic Value Studies (Javstudies), 3 (13), pp: 234-246.

Dereköy, Feyza (2020), "Nakit Akış Tablosu ile Likidite Oranları İlişkisi: Borsa İstanbul KOBİ Sanayi İşletmeleri Üzerine Bir Araştırma”, İşletme Araştırmaları Dergisi, 12 (4), ss. 3505-3517.

Derya Baskan, Tuba -Dozen, Büşra (2019), “Türkiye Muhasebe Standartlarına Göre İşletmelerin Nakit Akış Profillerinin BIST 100 Endeksi Üzerinde Analizi”, İşletme Araştırmaları Dergisi, 11 (4), ss. 3347-3357. 
Gup, Benton E. -Samson, William. D. - Dugan, Michael, T. -Kim, Myung.J.-Jittrapanun, Thawatchai (1993), “An Analysis of Patterns from the Statement of Cash Flows”, Financial Practice \& Education. 3 (2), pp. 73-79.

Gücenme, Ümit -Poroy Arsoy, Aylin (2006), "Muhasebe Standartlarındaki Sınıflandırılmış Nakit Akım Tablosu Formatı ile Finansal Performansın Ölçülmesi”, Muhasebe ve Finansman Dergisi, (30), ss. 66-74.

Karğın, Mahmut -Aktaş, Rabia (2011), “Türkiye Muhasebe Standartlarına Gore Raporlanmış Nakit Akış Tablosu ve Analizi”. Muhasebe ve Finansman Dergisi, (52), ss.1-25.

Ni, Yensen -Huang, Paoyu -Chianga, Pinhui -Liaoc, Yulu (2019), "Cash Flow Statements and Firm Value: Evidence from Taiwan”, The Quarterly Review of Economics and Finance, (71) February, pp. 280-290.

Orhan, Abdullah - Başar, Banu (2015), "İşletmelerde Nakit Akış Profilleri ve Analizi: BIST 100 İşletmeleri Üzerine Bir Uygulama”, Muhasebe ve Vergi Uygulamaları Dergisi, 8 (2), ss.107-122.

Özerhan, Yıldız -Yanık, Serap (2015), IFRS/IAS ile Uyumlu TMS/TFRS Açıklamalı ve Örnek Uygulamalı Türkiye Muhasebe Standartları Türkiye Finansal Raporlama Standartları, (3. Baskı), TÜRMOB Yayınları, Ankara.

Steinberga, Dzeina - Millere, Inta (2016), "Use of Cash Flow Statement in Evaluation of Company's Financial Situation Using Data From Operating and Liquidated Companies in The Republic of Latvia”, New Challenges of Economic and Business Development - May 12-14, Riga, University of Latvia, pp. 775-788.

Şensoy, Necdet (2002), Nakit Akış Tabloları, Yaylım Yayıncılık, İstanbul.

$\begin{array}{llll}\text { TMS } & 7 & \text { Nakit } & \text { Akış }\end{array}$ https://www.kgk.gov.tr/Portalv2Uploads/files/DynamicContentFiles/T\%C3\%BCrkiye \%20Muhasebe\%20Standartlar\%C4\%B1/TMSTFRS2019Seti/TMS/TMS\%207.pdf (Erişim Tarihi: 10. 03. 2021)

Williams, Jan R. - Haka, Susan F. - Bettner, Mark S. - Carcello, Joseph V. (2012), Financial and Managerial Accounting, New York, McGraw-Hill Irwin. 